\title{
Kesalahan Berbahasa Tataran Fonologi pada Pidato Juru Bicara Penanganan Virus Covid-19 Achmad Yurianto
}

\author{
Arina Mana Sikana ${ }^{1 凶}$, Antoni Agus Nugroho ${ }^{2 \bowtie} \&$ Pasiyah Tahe $^{3}$ \\ ${ }^{123}$ Institut Agama Islam Negeri Surakarta, Jawa Tengah, Indonesia \\ ${ }^{1}$ sikanaarina7@gmail.com, ${ }^{2}$ antoniagus23@gmail.com
}

\begin{abstract}
Language has rules that should be obeyed so that language users do not use it arbitrarily, and language must be used under correct linguistic rules. In fact, despite the rules of language, people still make mistakes in language, especially in the field of phonology. This study aims to describe language errors at the phonological level in the speech of the spokesman for handling the Covid-19 virus by Achmad Yurianto. The method used is descriptive qualitative. The data collection technique is to listen and note-taking on the utterances of words and sentences used by Achmad Yurianto. The data sources in this study were taken from the direct speech of speaker Achmad Yurianto in various mass media through the YouTube on March 9 to 23, 2020. The results showed three language errors at the phonological level, namely the removal of phonemes, both vowels, consonants, and mixtures; addition of phonemes, both vowels, and consonants; and phoneme changes which consist of changes in a vowel and consonant phonemes. The change in vowel phoneme is divided into two, namely changes in one vowel phoneme and two vowel phonemes.
\end{abstract}

Keywords: Covid-19, phonology, speech, viruses, language error

Abstrak: Bahasa memiliki aturan atau kaidah yang semestinya ditaati agar pengguna bahasa tidak semena-mena dalam menggunakannya serta bahasa tersebut digunakan sesuai dengan kaidah kebahasaan yang benar. Pada kenyataannya masyarakat masih banyak yang melakukan kesalahan dalam berbahasa, terutama dalam bidang Fonologi meskipun kaidah kebahasaan sudah ada. Penelitian ini bertujuan untuk menggambarkan kesalahan berhahasa pada tataran fonologi dalam pidato juru bicara penanganan virus Covid-19 oleh Achmad Yurianto. Penelitian ini menggunakan metode deskriptif kualitatif. Teknik pengumpulan data adalah simak dan catat pada tuturan kata dan kalimat yang dilakukan oleh Achmad Yurianto. Sumber data pada penelitian ini diambil dari tuturan langsung pembicara Achmad Yuianto dalam berbagai media masa melalui aplikasi youtube pada tanggal 9 sampai 23 Maret 2020. Hasil dari penelitian ini menunjukkan adanya tiga kesalahan berbahasa tataran fonologi yaitu penghilangan fonem baik vokal, konsonan, maupun campuran. Penambahan fonem baik vokal dan konsonan, dan perubahan fonem yang terdiri dari perubahan fonem vokal dan konsonan. Perubahan fonem vokal sendiri terbagi menjadi dua, yakni perubahan satu fonem vokal dan dua fonem vokal sekaligus.

Kata Kunci: Covid-19, fonologi, pidato, virus, kesalahan berbahasa

http://ejournal.iainbengkulu.ac.id/index.php/disastra

Copyright ( $) 2021$ Disastra: Jurnal Pendidikan Bahasa dan Sastra Indonesia

All rights reserved 


\section{Pendahuluan}

Bahasa merupakan alat komunikasi dalam kehidupan sehari-hari. Bahasa juga dapat dikatakan sebagai suatu alat bagi masyarakat dalam berkomunikasi untuk membina dalam diri manusia yang beraktualisasi, mendapatkan suatu kebahagian, terlepas dari suatu beban, serta demi kelangsungan hidupnya agar lebih baik (Prasetya, 2016:98). Namun, dalam penggunaan bahasa sering kali terjadi kesalahan baik disengaja ataupun tidak disengaja. Kesalahan berbahasa bisa terjadi akibat pengaruh kelengkapan alat ucap, kondisi geografis, pengaruh bahasa pertama, dan proses produksi huruf dalam bertutur kata. Ketika seseorang dalam berkomunikasi menggunakan beberapa bahasa sekaligus juga akan mempengaruhi adanya kesalahan dalam berbahasa. Hal ini dikarenakan satu bahasa tentu memiliki kaidah atau aturan kebahasaan yang berbeda dengan bahasa yang lain. Kesalahan berbahasa dapat terjadi di mana saja, baik dalam situasi formal maupun tidak formal.

Beberapa bulan ini seluruh negara sedang dikejutkan dengan virus Covid-19 dan tidak sedikit korban meninggal dari virus ini. Covid-19 pertama kali muncul di Wuhan Cina dan Badan Kesehatan Dunia (WHO) sudah menetapkan virus ini sebagai pandemi dengan wilayah persebaran mencakup antarnegara. Virus ini sudah menjangkiti berbagai negara seperti Amerika, Italia, Iran, Spanyol, Singapura, Malaysia, dan Indonesia. Indonesia juga menjadi salah satu negara yang terjangkit akan pandemi ini. Lebih dari enam belas ribu warga Indonesia positif terkena virus Covid-19 dan lebih dari sepuluh ribu orang sudah meninggal akibat virus ini, sehingga
Volume 3, Nomor 1, Januari 2021

ISSN 2655-3031 (P), 2655-7851 (O)

DOI: http://dx.doi.org/10.29300/disastra.v3i1.3185

tidak dapat dipungkiri pandemi ini sangat berbahaya.

Ketika Achmad Yurianto memberikan konferensi pers perkembangan virus Covid-19 terdapat kesalahan berbahasa seperti pengucapan kosakata yang tidak sesuai dengan aturan atau kaidah bahasa Indonesia. Hal tersebut sependapat dengan Batmang (2013:24) yang menyatakan kesalahan berbahasa merupakan kesenjangan kaidah bahasa yang menjadi gejala alami ketika proses belajar bahasa kedua. Kesalahan berbahasa pada pidato Achmad Yurianto ketika memberikan konferensi pers perkembangan virus Covid19 ini, dapat kita sebut dengan kesalahan Fonologi. Fonologi merupakan suatu ilmu yang menelaah dengan teliti mengenai fonem-fonem yang ada pada bahasa (Mulyaningsih, 2014:3). Fonologi juga dapat dikatakan sebagai cabang ilmu linguistik yang mempelajari, menelaah, serta membicarakan runtutan bunyi-bunyi pada suatu bahasa (Chaer, 2014:102).

Kesalahan fonologi terjadi ketika pegucapan suatu fonem tidak sesuai dengan kaidah kebahasaan seperti huruf /b/ menjadi /p/, /f/ menjadi /p/, dan /i/ menjadi /e/. Kesalahan dalam bidang fonologi terjadi akibat produksi kata dalam alat ucap tidak sesuai dengan artikulasi sehingga mempengaruhi ragam bahasa lisan dan tulis (Ghufron, 2015:96). Setyawati (2010:23) juga memiliki opini bahwa kesalahan berbahasa dalam bidang fonologi meliputi penghilangan, perubahan, dan penambahan fonem. Kesalahan berbahasa sering terjadi oleh pengaruh bahasa pertama, kebiasaan memakai kosakata salah, dan tidak ada kemauan untuk mempelajari bahasa (Richards, 1978:102). Kesalahan berbahasa juga dapat disebabkan karena perbedaan 
kontak antara bahasa bahasa ibu dan bahasa kedua yang digunakan (Setyowati, dkk: 2019:2). Kesalahan dalam berbahasa juga perlu ditinjau dari artikulasi penutur sehingga dapat diketahui perbedaan dan fungsi pemakaian kata yang digunakan (Sasangka, 2011:4). Manfaat dari analisis kesalahan berbahasa dapat memperbaiki dan membantu proses belajar mengajar bahasa sasaran, serta dapat membantu pengajar dalam mengklasifikasi kesalahan berbahasa secara lebih terarah (Inderasari \& Agustina, 2017:8).

Kesalahan berbahasa, khususnya bidang fonologi bisa terjadi pada siapa saja dan di mana saja, salah satunya dalam pidato Achmad Yurianto mengenai perkembangan Covid-19 yang ada di Indonesia. Sebagai pekerja di lembaga pemerintahan dan menjadi pusat perhatian sebagai juru bicara presiden dalam menangani pandemi global, Achmad Yurianto seharusnya menjadi contoh bagi masyarakat dalam berbahasa Indonesia yang baik dan benar sesuai dengan kaidah kebahasaan yang ada.

Penelitian yang relevan mengenai kesalahan berbahasa bidang fonologi terdapat pada penelitian "Analisis Kesalahan Berbahasa pada Bahan Ajar Kelas Menyimak Program BIPA IAIN Surakarta" yang dilakukan oleh Tiya Agustina dan Wahyu Oktavia pada tahun 2019. Dari penelitian tersebut ditemukan adanya kesalahan berbahasa bidang fonologi, yakni adanya penambahan fonem, penghilangan fonem, dan perubahan fonem suatu kata.

Berdasarkan latar belakang yang telah diuraikan adapun tujuan dalam penelitian ini untuk mengetahui kesalahan berbahasa tataran fonologi agar makna
Volume 3, Nomor 1, Januari 2021

ISSN 2655-3031 (P), 2655-7851 (O)

DOI: http://dx.doi.org/10.29300/disastra.v3i1.3185

kalimat dapat dimengerti dan tersampaikan dengan baik oleh masyarakat sehingga tidak ada lagi multitafsir dalam memahami pidato Achmad Yurianto.

\section{Metode Penelitian}

Metode dalam penelitian ini memakai deskriptif kualitatif. Penelitian deskriptif merupakan penelitian yang disusun untuk mendapatkan informasi mengenai keadaan suatu gejala yang ada saat penelitian berlangsung (Lexy, 2012:47). Informasi yang dipaparkan berupa wujud dari kesalahan berbahasa bidang fonologi pada pidato juru bicara penanganan Covid19 Achmad Yurianto. Metode penelitian kualitatif juga dikatakan sebagai metode penelitian yang digunakan untuk meneliti pada kondisi objek yang alami (Sugiyono, 2014:9). Sumber data dalam penelitian ini berupa tuturan kata dan kalimat pada saat Achmad Yurianto melakukan pidato mengenai perkembangan virus corona di Indonesia. Teknik pengumpulan data yang digunakan ialah simak dan catat ketika Achmad Yurianto melaporkan perkembangan kasus Covid-19 di Indonesia. Teknik ini dilakukan dengan cara mendengarkan secara saksama sumber data yang diperoleh kemudian dilakukan penyimakan terhadap sumber data tersebut. Tahap terakhir ialah mencatat data yang sudah diperoleh. Penggunaan teknik simak dan catat akan memudahkan peneliti, karena dapat terjun langsung ke sumber masalah. Sumber data dalam penelitian ini diambil dari tuturan langsung Achmad Yuianto dalam berbagai media masa melalui aplikasi youtube pada tanggal 9 samapi 23 Maret 2020.

Analisis yang digunakan dalam penelitian ini adalah correc analysis atau

Arina Mana Sikana, Antoni Agus Nugroho, Pasiyah Tahe

Kesalahan Berbahasa Tataran Fonologi pada Pidato Juru Bicara Penanganan Virus Covid-19 Achmad Yurianto 
kesalahan. Chrystal (dalam Pateda, 2001:32) menjelaskan bahwasanya analisis kesalahan ialah suatu cara untuk menentukan, mengklasifikasikan, serta menafsirkan dengan teratur berdasarkan teori serta prosedur yang didasarkan pada ilmu linguistik. Adapun tahap-tahap yang digunakan dalam penelitian ini ialah pengumpulan data yang akan digunakan, menentukan kesalahan, penjabaran kesalahan, pengklasifikasian kesalahan, serta mengevaluasi kesalahan yang ada.

\section{Hasil dan Pembahasan}

Kesalahan berbahasa dalam bidang fonologi merupakan kesalahan berbahasa yang dapat ditemui melalui pengucapan bunyi bahasa dari alat ucap manusia. Alat ucap manusia menjadi peranan yang paling penting karena alat ucap tersebut nantinya menghasilkan bunyi bahasa. Bunyi bahasa yang dihasilkan tersebut sangat mempengaruhi ada atau tidaknya kesalahan berbahasa dalam tataran fonologi.

Bunyi bahasa atau fonem pada dasarnya saling berkaitan dalam runtutan bunyi (Chaer, 2013:96). Karena saling berkaitan fonetis maupun fonemis dapat mempengaruhi bunyi-bunyi tersebut. Ini pula yang mengakibatkan adanya kesalahan berbahasa bidang fonologi, seperti penghilangan fonem, penambahan fonem, dan perubahan fonem. Berikut data hasil analisis terkait pidato juru bicara penanganan virus Covid-19 Ahmad Yurianto.

\section{Kesalahan Berbahasa Tataran Fonologi}

\begin{tabular}{|l|l|l|l|}
\hline No & $\begin{array}{l}\text { Kesalaan } \\
\text { Fonologi }\end{array}$ & $\begin{array}{l}\text { Ujaran } \\
\text { Salah }\end{array}$ & $\begin{array}{l}\text { Ujaran } \\
\text { Benar }\end{array}$ \\
\hline 1. & $\begin{array}{l}\text { Penghila } \\
\text { ngan }\end{array}$ & Karna & Karena \\
\hline
\end{tabular}

\begin{tabular}{|l|l|l|}
\hline Fonem & & \\
\hline \multirow{y}{*}{} & Priksa & Periksa \\
\cline { 2 - 3 } & Taun & Tahun \\
\cline { 2 - 3 } & Negri & Negeri \\
\cline { 2 - 3 } & Tuju & Tujuh \\
\cline { 2 - 3 } & Abis & Habis \\
\cline { 2 - 3 } & Diabet & Diabetes \\
\cline { 2 - 3 } & Masarakat & Masyarakat \\
\cline { 2 - 3 } & Mengubun & Menghubu \\
gi & ngi \\
\cline { 2 - 3 } & Bawa & Bahwa \\
terdapat & terdapat \\
& penambah & penambaha \\
n... \\
\hline
\end{tabular}

Pada data di atas dapat kita analisis adanya penghilangan fonem pada kata atau ujuran pidato yang dilakukan oleh Achmad Yurianto selaku juru bicara penangan virus Covid-19.

$$
\text { Data (1) "Karna" dan data (2) }
$$
"Priksa", kata tersebut terdapat penghilangan fonem vokal /e/, yang seharusnya diucapkan [Karena] dan [Periksa]. Data (3) “Taun” juga mengalami penghilangan fonem, namun fonem konsonan /h/, yang seharusnya diucapkan [Tahun]. Pada data (4) "Negri", terdapat penghilangan fonem vokal /e/, seharusnya [Negeri]. Data (5) “Tuju", data (6) "Abis", dan data (9) "Mengubungi" juga mengalami penghilangan fonem konsonan /h/. Seharusnya diucapkan [Tujuh], [Habis], dan [Menghubungi]. Kata "Diabet" pada data (7) terdapat penghilangan fonem vokal dan konsonan sekaigus, yakni fonem /e/ dan /s/ yang seharusnya [Diabetes]. Kata "Masarakat" pada data (8) mengalami penghilangan fonem konsonan /y/. Kata yang tepat adalah [Masyarakat]. Data terakhir (11) "Bawa terdapat penambahan...", mengalami penghilangan fonem /h/ seperti data (5), (6), dan (10). 
Dari analisis di atas dapat disimpulkan bahwasanya terdapat kesalahan berbahasa tataran fonologi, yakni penghilangan fonem vokal, konsonan, dan campuran (vokal dan konsonan).

\begin{tabular}{|c|c|c|c|}
\hline No & $\begin{array}{l}\text { Kesalaha } \\
\text { n } \\
\text { Fonologi }\end{array}$ & $\begin{array}{l}\text { Ujuran } \\
\text { Salah }\end{array}$ & $\begin{array}{l}\text { Ujaran } \\
\text { Benar }\end{array}$ \\
\hline \multirow[t]{9}{*}{1.} & $\begin{array}{l}\text { Penamba } \\
\text { han } \\
\text { fonem }\end{array}$ & Jugak & Juga \\
\hline & & Iyak & Iya \\
\hline & & Tanyak & Tanya \\
\hline & & $\begin{array}{l}\text { Menghimba } \\
\mathrm{u}\end{array}$ & Mengimbau \\
\hline & & Setabil & Stabil \\
\hline & & Ribuw & Ribu \\
\hline & & Yak & $\mathrm{Ya}$ \\
\hline & & Standart & Standar \\
\hline & & Banyakkan & Banyakan \\
\hline
\end{tabular}

Dari data di atas terdapat sembilan kata yang mengalami kesalahan fonologi penambahan fonem. Misal pada data (1) "Jugak", (2) "Iyak", dan data (3) "Tanyak". Ketiga kata tersebut mengalami penambahan fonem konsonan $/ \mathrm{k} /$ sehingga ujaran yang terjadi tidak sesuai dengan kaidah kebahasaan. Kata yang benar ialah [Juga], [Iya], dan [Tanya]. Kata "Menghimbau" pada data (4) juga mengalami penambahan fonem konsonan /h/. Karena kata tersebut berasal dari kata dasar imbau yang mendapatkan prefiks $m e(N)$, sehingga yang benar ialah [Mengimbau].

Selanjutnya data (5) "Setabil", mendapatkan penambahan fonem vokal /e/ yang seharusnya [Stabil]. Kata "Ribuw" pada data (6) mendapatkan penambahan fonem konsonan /w/, yang seharusnya ujuran tersebut diucapkan tanpa imbuhan fonem /w/, [Ribu]. Data (7) sama seperti pada data satu sampai tiga, yang seharusnya pelafalan yang dilakukan tidak menambahkan fonem konsonan $/ \mathrm{k} /$. Sehingga yang benar [Ya]. Pada kata "Standart" atau data (8) juga mendapatkan imbuhan fonem konsonan /t/, seharusnya $\mathrm{s} / \mathrm{t} / \mathrm{a} / \mathrm{n} / \mathrm{d} / \mathrm{a} / \mathrm{r}$ tanpa imbuhan konsonan /t/ diakhir kata. Pada data (9) "Banyakkan" juga mendapatkan penambahan fonem $/ \mathrm{k} /$, seharusnya [banyakan] yang memiliki arti lebih banyak atau lebih umum.

Dari analisis tabel kedua dapat disimpulkan bahwasanya kesalahan berbahasa tataran fonologi pada penambahan fonem terdapat dua jenis penambahan fonem, yaitu vokal dan konsonan sejumlah sembilan kata.

\begin{tabular}{|c|c|c|c|}
\hline No & $\begin{array}{l}\text { Kesalahan } \\
\text { Fonologi }\end{array}$ & $\begin{array}{l}\text { Ujaran } \\
\text { Salah } \\
\end{array}$ & $\begin{array}{l}\text { Ujaran } \\
\text { Benar }\end{array}$ \\
\hline \multirow[t]{22}{*}{1.} & $\begin{array}{l}\text { Perubahan } \\
\text { fonem }\end{array}$ & Melakuken & Melakukan \\
\hline & & Kemaren & Kemarin \\
\hline & & Malem & Malam \\
\hline & & Sampek & Sampai \\
\hline & & Propinsi & Provinsi \\
\hline & & Membaek & Membaik \\
\hline & & Pemerentah & Pemerintah \\
\hline & & Haselnya & Hasilnya \\
\hline & & Baek & Baik \\
\hline & & Sebage & Sebagai \\
\hline & & Saket & Sakit \\
\hline & & Pasyen & Pasien \\
\hline & & Pemereksaan & Pemeriksaan \\
\hline & & Nomer & Nomor \\
\hline & & Nampak & Tampak \\
\hline & & Selesei & Selesai \\
\hline & & Pakek & Pakai \\
\hline & & Pake & Pakai \\
\hline & & Miskipun & Meskipun \\
\hline & & Molai & Mulai \\
\hline & & Jatoh & Jatuh \\
\hline & & Konsoltasi & Konsultasi \\
\hline
\end{tabular}


LPJISISASTRA

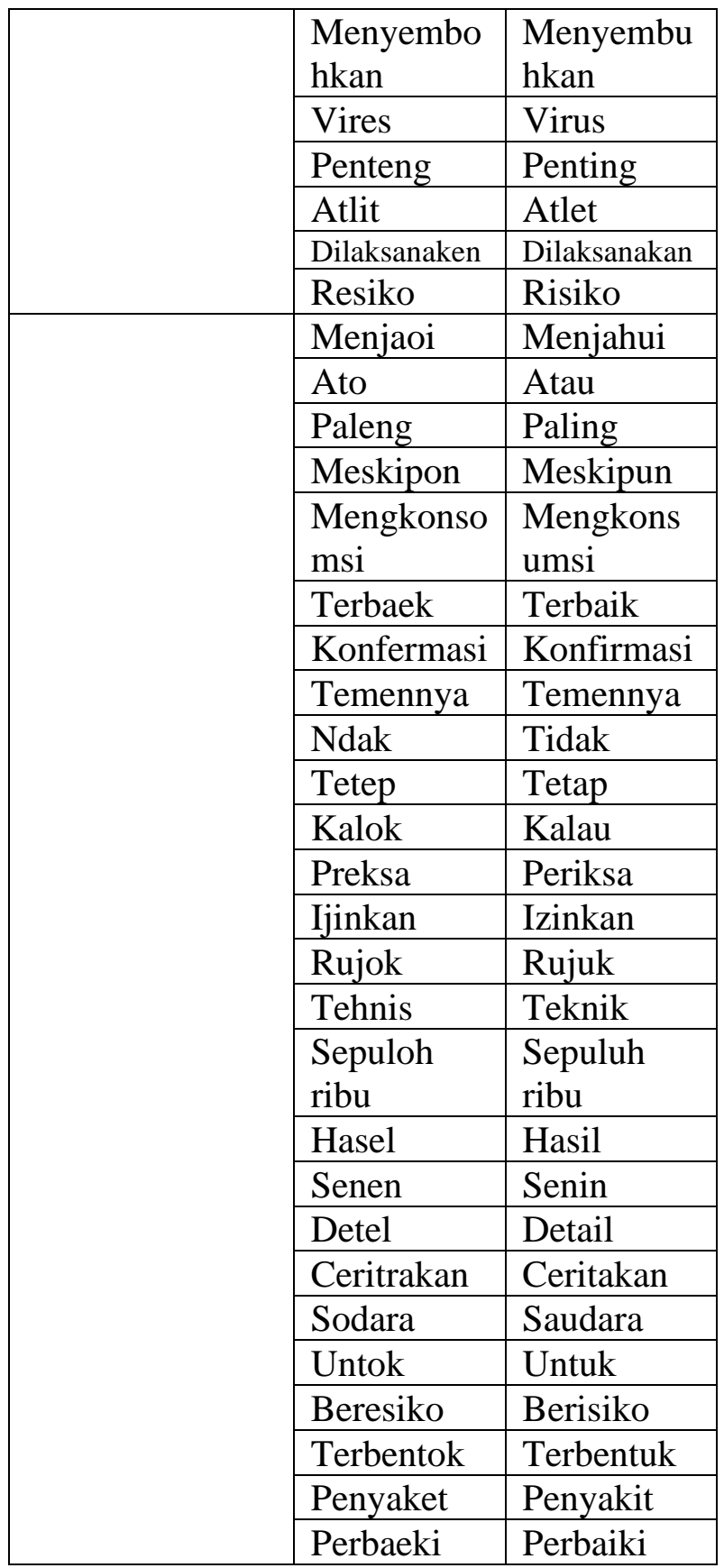

Tabel terakhir merupakan data dari analisis kesalahan berbahasa tataran fonologi perubahan fonem pada pidato Achmad Yurianto selaku juru bicara penangan virus Covid-19 di Indonesia.

Dari data di atas kesalahan berbahasa tataran fonologi perubahan fonem memiliki jumlah yang banyak dibandingkan dengan kesalahan penambahan maupun penghilangan fonem.
Volume 3, Nomor 1, Januari 2021

ISSN 2655-3031 (P), 2655-7851 (O)

DOI: http://dx.doi.org/10.29300/disastra.v3i1.3185
Kita amati pada data

"Kemaren", ujaran tersebut tentu salah dan mengalami perubahan fonem vokal /i/ jadi /e/, kata yang benar seharusnya [Kemarin]. Data (5) "Propinsi", juga mengalami perubahan fonem konsonan dari /v/ menjadi /p/. Ujaran yang benar seharusnya [Provinsi].

Selanjutnya data (47) "Sodara". Kata yang benar seharusnya [Saudara]. Sehingga pada data (47) mengalami perubahan dua fonem sekaligus, yakni fonem vokal /a/ dan /u/ menjadi fonem /o/.

Dari seluruh data yang tertera pada tabel tiga secara keseluruhan mengalami perubahan fonem seperti analisis yang dipaparkan. Data yang mengalami perubahan fonem sejumlah lima puluh dua kata. Jumlah yang cukup banyak jika dibandingkan dengan penambahan maupaun penghilangan fonem. Dari penjabaran tersebut dapat disimpulkan bahwasanya terdapat kesalahan berbahasa tataran fonologi perubahan fonem, baik vokal maupun konsonan sejumlah lima puluh dua kata.

Adanya kesalahan berbahasa tataran fonologi tersebut tentu dilatarbelakangi oleh beberapa faktor. Baik secara intermal maupun eksternal.

Faktor internal dapat kita lihat dari beberapa hal. Pertama, kurangnya pemahaman si penutur mengenai bahasa yang baik dan benar. Kurangnya pemahaman ini menjadikan penutur tidak merasa melakukan kesalahan dalam berbahasa. Sehingga bahasa yang diujarkan sehari-hari sudah dijadikan patokan bahwa itu benar. Faktor kedua adalah adanya pembiasaan penggunaan kata yang tidak sesuai kaidah dalam berbahasa. Hal ini dapat kita lihat dari video yang kami simak

Arina Mana Sikana, Antoni Agus Nugroho, Pasiyah Tahe

Kesalahan Berbahasa Tataran Fonologi pada Pidato Juru Bicara Penanganan Virus Covid-19 Achmad Yurianto 
sebagai objek penelitian. Dari keenam video yang kami amati penutur melakukan kesalahan berbahasa tataran fonologi secara berulang. Pembiasaan inilah yang mengakibatkan penutur kurang menyadari adanya kesalahan berbahasa saat berujar.

Selain faktor internal seperti pemaparan sebelumnya, faktor yang mempengaruhi adanya kesalahan berbahasa ialah dari luar si penutur atau disebut eksternal. Pertama faktor lingkungan. Penutur tinggal di lingkungan metropolitan. Otomatis berkecimpung dengan orang-orang metropolitan pula. Banyak masyarakat metropolitan yang menggunakan bahasa gaul dalam berkomunikasi sehari-hari. Begitu pula pada penutur dalam objek penelitian ini. Karena lingkungan masyarakatnya sering menggunakan bahasa gaul secara tidak langsung si penutur juga terpengaruh, misal pada saat mengucapkan kata Teman si penutur mengucapkan dengan Temen. Kedua adalah situasi penutur saat melakukan ujaran. Hal ini dapat dilihat ketika penutur melakukan ujaran dalam situasi yang genting karena virus Covid-19 yang memberlakukan menghindari keramaian, hal itu menjadikan si penutur untuk mempercepat pidato yang diberikan di depan para media dan wartawan. Kondisi ini menjadikan penutur menggunakan bahasa yang sekiranya mampu untuk dipahami pendengar tanpa harus memikirkan kaidah kebahasaan. Sehingga penutur menggunakan bahasa yang sekiranya mudah dan dipahami.

\section{Simpulan}

Berdasarkan hasil penelitian dan pembahasan yang dilakukan tentang analisis kesalahan berbahasa tataran fonologi pada pidato juru bicara penangan virus Covid-19
Volume 3, Nomor 1, Januari 2021

ISSN 2655-3031 (P), 2655-7851 (O)

DOI: http://dx.doi.org/10.29300/disastra.v3i1.3185

Achmad Yurianto, ditemukan simpulan sebagai berikut. Pertama, analisis kesalahan berbahasa tataran fonologi penghilangan fonem vokal, konsonan maupun campuran. Penghilangan fonem vokal, misalnya kata Tuju, yang menghilangkan fonem konsonan /h/, seharusnya [Tujuh]. Contoh penghilangan fonem vokal pada kata Karna yang menghilangkan fonem vokal /e/, yang benar [Karena]. Kemudian contoh penghilangan fonem campuran terlihat dari kata Diabet yang menghilangkan fonem /e/ dan /s/, seharusnya [Diabetes]. Selain penghilangan fonem juga terdapat penambahan fonem pada ujuaran yang dilakukan sehingga menjadikan ujuran tersebut mengalami kesalahan berbahasa.

Penambahan fonem juga terdapat dua, yakni penambahan fonem vokal dan konsonan. Misal pada kata Setabil yang mengalami penambahan fonem vokal /e/, seharusnya [Stabil] tanpa adanya penambahan vokal /e/. Penamabahan fonem konsonan terlihat pada kata Tanyak, yang mendapatkan imbuhan fonem konsonan $/ \mathrm{k} /$, yang benar adalah [Tanya] tanpa imbuhan fonem konsonan $/ \mathrm{k} /$, yang terakhir adalah adanya perubahan fonem vokal dan konsonan. Perubahan fonem vokal dibagi menjadi dua, yakni perubahan satu fonem vokal dan dua fonem vokal. Kata Vires mengalami perubahan satu fonem vokal yaitu fonem vokal yang seharusnya /u/ menjadi /e/, kata yang benar adalah [virus]. Kemudia kata Sodara mengalami perubahan dua fonem vokal yakni dari fonem /a/ dan /u/ menjadi fonem vokal /o/, kata yang benar ialah [Saudara]. Selanjuutnya contoh dari perubahan fonem konsonan pada kata Propinsi yang seharusnya fonem /v/ menjadi $/ \mathrm{p} /$, kata yang benar adalah [Provinsi]. 
LDJDISASTRRA

Daftar Pustaka

Agustina, T \& Oktavia, W. (2019). "Analisis

Kesalahan Berbahasa pada Bahan

Ajar Kelas Menyimak Program BIPA IAIN Surakarta”. Disastra, 1 (38).

Batmang. (2013). "Kesalahan Fonologis dalam Bericara Bahasa Arab pada Mahasiswa Matrikulasi STAIN Kendari”. Al Izzah, 8(1).

Chaer, A. (2013). Fonologi Bahasa Indonesia. Jakarta: Rineka Cipta.

Chaer, A. (2014). Linguistik Umum. Jakarta: Rineka Cipta.

Ghufron, S. (2015). Kesalahan Berbahasa Indonesia: Teori dan Aplikasi. Yogyakarta: Penerbit Ombak.

Inderasari, E \& Tiya, Agustina. (2017). "Pembelajaran Bahasa Indonesia Mahasiswa Asing dalam Program BIPA IAIN Surakarta". Jurnal Pendidikan Bahasa dan Sastra Indonesia, 6 (2).

Lexy, J. M. (2012). Metodologi Penelitian Kualitatif. Bandung: PT. Remaja Rosdakarya.

Mulyaningsih, D. H. (2014). "Perbandingan Fonologi Bahasa Indonesia dan Bahasa Mandarin". Bahtera, 1.

Pateda, M. (2001). Semantik Leksikal. Jakarta: Rineka Cipta.

Prasetya, T. (2016). "Kosakata Sehari-hari

Kelompok Transeksual di

Kecamatan Pakis Kabupaten Malang". Kembara, 2 (1).

Richard, J. E. (1978). Analysis Perspectives on Second Language. London: Longman Group Limited.

Sasangka, S. S. T. W. (2011). Bunyi-Bunyi Distingtif Bahasa Jawa.

Yogyakarta: Elmatera Publishing.
Volume 3, Nomor 1, Januari 2021

ISSN 2655-3031 (P), 2655-7851 (O)

DOI: http://dx.doi.org/10.29300/disastra.v3i1.3185

Setyawati, Nanik. (2010). Analisis

Kesalahan Berbahasa Indonesia:

Teoridan Pragtik. Surakarta:

Yuma pustaka.

Setyowati, Ilma Dzina., Sulistiyawati, E., \&

Cahyaningrum, G. R. 2019.

"Analisis Kesalahan Berbahasa

Tataran Fonologi dalam Laporan

Hasil Observasi Siswa". Jurnal

Bindo Sastra, 3(1).

Sugiyono. 2014. Metode Penelitian Pendidikan Kuantitatif, Kuallitatif, dan $R \& D$. Bandung: Alfabeta. 